\title{
To What Extend Does The Technology Disrupstion Affect The Sale Of Smes Banana Chips Products In Bandar Lampung?
}

\author{
Helmia Adita Fitra1 , Fran Sinatra2 \\ ${ }^{1,2}$ Institut Teknologi Sumatera, Lampung Selatan, Lampung
}

\begin{abstract}
Small and Medium-Sized Enterprises (SMEs) in Indonesia, which is also known as Usaha Mikro Kecil dan Menengah (UMKM), play a significant role in determining national economic performance. Banana chips are the most well-known product in Bandar Lampung. As the provincial capital of Lampung Province, Bandar Lampung becomes the center of trade and services sector which is a vital sector of the downstream industry activity. One of the vital aspect in the downstream of Banana chips industry is selling. This study aims to examine the effect of disruptive technology on the sale of SMEs Banana Chips products in Bandar Lampung. This study conduct the quantitative approach by using multiple regression linear analysis. The findings show that the regression model of selling aspect has 0.594 in R2 value. It means that the regression model is able to represent the real condition about $59,4 \%$. According to the model, among the 6 (six) predictor variables, the most-influencing variable on the sale of Banana chips products is online-based promotion.
\end{abstract}

Keywords. SMSEs, Technology Disruption, Regression, Banana Chips, Lampung

\section{Introduction}

The existence of technology disruption effects the development in many ways. Disruptive technology clearly emphasizes the easiness, in terms of reducing the mobility, in order to meet people needs. However, the biggest challenge in facing disruptive technology era is infrastructure preparedness both hard infrastructure such as fiber optic network and soft infrastructure such as policy. As one of significant sectors in determining local and regional development, Indonesian Government should have formulated industrial policy in facing the era of disruptive technology (Sulaksono, 2018). Law no. 3 of 2014 about National Industry puts industrial sector as one of primary economic sector in Indonesia. The vision of national industrial development in Indonesia is becoming a formidable industrial country which is seen from 3 characteristics: 1) a strong and equitable national industrial structure, 2) highly competitive industries at global level 3) innovation and technology-based industrial activities (Ministry of Industry, 2015). As one of strategies in pursuing the vision of national industry, Indonesian Government formulate an affirmative policy for small and medium industries.

Small and Medium-Sized Enterprises (SMEs) in Indonesia, which is also known as Usaha Mikro Kecil dan Menengah (UMKM), play a significant role in determining national economic performance. According to Bank Indonesia (2012), the existence of SMEs in Indonesia is quite dominant in determining both national and local economic performance. As the provincial capital of Lampung Province, Bandar Lampung plays a strategic roles in regional development especially in the development of Sumatera. Industrial activities in Bandar Lampung should have become one of the backbone of regional economic. However, according to Gross Regional Domestic Product (GDRP) of Bandar Lampung from 2010 to 2016, the growth average of industry sector is only 5,75\% annually which placed the industry sector in $11^{\text {th }}$ position of 17 sectors. Referring to Badan Pusat Statistik Kota Bandar Lampung (2016), in 2014 the number of industrial units in Bandar Lampung reached 9.908 units with the proportion is $2 \%$ for medium-large industries, $25 \%$ for small industries and $75 \%$ for home industries. Data from BPS Bandar Lampung (2016) revealed that home industry in Bandar Lampung has the biggest number. Banana chips are the most well-known product in Bandar Lampung which produced by SMEs Banana chips in Bandar Lampung. Banana chips industries has been seen as a vital asset in local economic development and employment promotion in Bandar Lampung.

As the biggest city in Lampung Province, Bandar Lampung becomes the center of trade and services sector which is a vital sector of the downstream industry activity. One of the vital aspect in the downstream of Banana chips industry is selling. The existence of disruptive technology is undeniable and directly force the small and medium industries to upgrade and to adapt the shift of customer demands to their products. Those who cannot adapt and upgrade their innovation will be left behind 
(Windell in Chishkwe and Smith, 2012). This study aims to examine about to what extent the disruptive technology affects the sale of SMEs banana chips products in Bandar Lampung. The study is conducted in Jl. Pagar Alam, which is most-well known as Gang PU, as the center of SMEs Banana Chips in Bandar Lampung.

\section{Methodology}

The research object of this study is SMEs Banana Chips in Gang PU, Bandar Lampung. There are 23 SMEs Banana Chips there. This study develops variable by elaborating the concept of disruptive technology and the aspects in developing SMEs. Zanni (2017) revealed the habitude of disruptive technology era is shown by 1) the use of internet in industrial business process, 2) robotic technology utilization in industrial business process, 3 ) the use of artificial intelligence in industrial business process and 4) the computational data usage in industrial business. Therefore, this study involves annual average of the sale of banana chips as dependent variable and the habitudes of disruptive technology era as the predictor variables. Here is the predictor variables in this study: 1) the number of sales via internet/ online transaction $(\mathrm{kg}), 2$ ) the number of sales by using delivery service $(\mathrm{kg}), 3$ ) the number of sales abroad $(\mathrm{kg}), 4)$ the number of product sales outside Lampung Province $(\mathrm{kg}), 5)$ the number of product sales outside of Bandar Lampung $(\mathrm{kg}), 6$ ) internet-based product promotion (dummy variable). This study conducts multiple linear regression analysis. Instead of sampling, this study uses all population in the analysis.

\section{Findings and Analysis}

The glance of SMEs Banana Chips in Gang PU Bandar Lampung shows us that the trend of product sales is decline. The average decline in sales of banana chips from 2012 to 2017 is approximately 3.858 kg per year (Table 1).

\begin{tabular}{|c|c|c|}
\hline No & SMEs Banana Chips & $\begin{array}{c}\text { Sales Difference in 2012 and 2017 } \\
\text { (in } \mathbf{~} \text { ) }\end{array}$ \\
\hline 1 & Keripik Siger & 800 \\
\hline 2 & Keripik AHHAS & 300 \\
\hline 3 & Jom-Jom & $-9,000$ \\
\hline 4 & Keripik Royon & 0 \\
\hline 5 & Oleh-Oleh Khas Lampung "Wisa" & -300 \\
\hline 6 & Keripik Nayla & 2,000 \\
\hline 7 & Cesylia & $-1,000$ \\
\hline 8 & Saudagar & 200 \\
\hline 9 & Arabar Shop & $-10,220$ \\
\hline 10 & Keripik Wagiman & $-32,850$ \\
\hline 11 & Keripik Rizka & 12,000 \\
\hline 12 & Askha Jaya 1 & 12,000 \\
\hline 13 & Askha Jaya 2 & 12,000 \\
\hline 14 & Askha Jaya 3 & 12,000 \\
\hline 15 & Askha Jaya 4 & $-3,600$ \\
\hline 16 & Sumber Rezeki & $-24,000$ \\
\hline 17 & Puri Jaya 1 & $-24,000$ \\
\hline 18 & Puri Jaya 2 & $-24,000$ \\
\hline 19 & Puri Jaya 3 & $-24,000$ \\
\hline 20 & Puri Jaya 4 & \\
\hline & & \\
\hline
\end{tabular}


ICOSITER 2018 Proceeding Journal of Science and Applicative Technology

\begin{tabular}{|c|c|c|}
\hline No & SMEs Banana Chips & $\begin{array}{c}\text { Sales Difference in 2012 and 2017 } \\
\text { (in } \mathrm{Kg} \text { ) }\end{array}$ \\
\hline 21 & Ali Baba & 2,400 \\
\hline 22 & Keripik Yaya & 14,400 \\
\hline \multicolumn{2}{|c|}{ Average Sales Difference } & $-\mathbf{3 , 8 5 8}$ \\
\hline
\end{tabular}

Table 1. Sales Difference of SMEs Banana Chips in 2012 and 2017

The sales is an important aspect in determining the sustainable of SMEs Banana Chips business in Bandar Lampung. By using regression analysis, the study about the impact of disruptive technology on the sales of SMEs Banana Chips products can be revealed. Here is the regression model:

\section{Information:}

$$
Y=-39.130,96+21.842,16 X_{1}
$$

$$
\begin{array}{ll}
\mathrm{Y} & =\text { The number of sold banana chips products (Banana Chips) }(\mathrm{kg}) \\
\mathrm{X}_{1} & =\text { Internet-based product promotion (dummy variable) } \\
\mathrm{X}_{2} & =\text { The number of sales by using delivery service }(\mathrm{kg}) \\
\mathrm{X}_{3} & =\text { The number of product sales by using online transaction }(\mathrm{kg}) \\
\mathrm{X}_{4} & =\text { The number of sales abroad }(\mathrm{kg}) \\
\mathrm{X}_{5} & =\text { The number of sales outside of Lampung Province }(\mathrm{kg}) \\
\mathrm{X}_{6} & =\text { The number of sales outside of Bandar Lampung }(\mathrm{kg})
\end{array}
$$

\begin{tabular}{|c|c|c|c|c|c|c|}
\hline & \multirow[t]{2}{*}{ Model } & \multicolumn{2}{|c|}{ Unstandardized Coefficients } & \multirow{2}{*}{$\begin{array}{c}\begin{array}{c}\text { Standardized } \\
\text { Coefficients }\end{array} \\
\text { Beta }\end{array}$} & \multirow[b]{2}{*}{$t$} & \multirow[b]{2}{*}{ Sig. } \\
\hline & & B & Std. Error & & & \\
\hline \multirow[t]{7}{*}{1} & (Constant) & -39130.969 & 8757.019 & & -4.469 & .000 \\
\hline & ol_promotion & 21842.169 & 5652.278 & .792 & 3.864 & .002 \\
\hline & delivery_service & 42.011 & 51.083 & .196 & .822 & .424 \\
\hline & transaction_ol & -1.413 & 3.294 & -.091 & -.429 & .674 \\
\hline & sells_abroad & -33.777 & 36.859 & -.208 & -.916 & .374 \\
\hline & sells_province & 17.139 & 30.361 & .162 & .564 & .581 \\
\hline & sells_city & 21.636 & 52.023 & .073 & .416 & .683 \\
\hline
\end{tabular}

The value of $\mathrm{R}^{2}$ of the model is 0,594 . The values are assumed that the model can represent about $59,4 \%$ of real condition. Referring to the model, it is shown that only 1 (one) significant independent variable that can be a predictor variable in this model while the other variables are not significant enough to determine the model since they have the level of significance is higher that 0,05 . The variable is "internet-based product promotion". Here is the table of significance level of independent variables:

a. Dependent Variable: sold_product

Table 2. The Level of Significance of Independent Variables

According to the table, it is known that B value in Under standardized Coefficients for each variable is vary.

The model reveals that disruptive technology has not affected all aspects in sales product except the promotion with internet-based only. SMEs Banana Chips in Bandar Lampung already use the social media and internet to promote and market their product by using some internet features such as Instagram, WhatsApp, Facebook and any online shop. The reliability of the model can be rechecked by using the existing the sales difference data of SMEs Banana Chips 2012 and 2017 and the internet usage data of product promotion (Table 3 ).

\begin{tabular}{|c|c|c|c|}
\hline No & $\begin{array}{c}\text { SMEs Banana } \\
\text { Chips }\end{array}$ & $\begin{array}{c}\text { Sales } \\
\text { Difference } \\
\text { (in Kg) }\end{array}$ & $\begin{array}{c}\text { Internet- } \\
\text { based in } \\
\text { Product } \\
\text { Promotion }\end{array}$ \\
\hline 1 & Jom-Jom & -9000 & No \\
\hline 2 & Keripik Royon & 0 & No \\
\hline
\end{tabular}


ICOSITER 2018 Proceeding Journal of Science and Applicative Technology

\begin{tabular}{|c|c|c|c|}
\hline 3 & Cesylia & -1000 & No \\
\hline 4 & Keripik Rizka & -32850 & No \\
\hline 5 & Puri Jaya 1 & -24000 & No \\
\hline 6 & Puri Jaya 2 & -24000 & No \\
\hline 7 & Puri Jaya 3 & -24000 & No \\
\hline 8 & Puri Jaya 4 & -24000 & No \\
\hline 9 & Ali Baba & 2400 & No \\
\hline \multicolumn{2}{|l|}{ Average Sales Difference } & -15161.111 & No \\
\hline
\end{tabular}

Table 3. The Sales Difference of 2012 and 2017 Without Using Internet in Product Promotion

Table 3 shows that those who do not use the internet to promote their product will have a big loss. It can be seen by the average sales difference of 2012 and 2017 that extremely decline about $15.161 \mathrm{~kg}$. Meanwhile, the SMEs that conduct the internet-based product promotion have benefits in sales. It is shown on Table 4 that the average sales difference between 2012 and 2017 had increased about 3.967 $\mathrm{kg}$.

\begin{tabular}{|c|c|c|c|}
\hline No & $\begin{array}{c}\text { SMEs Banana } \\
\text { Chips }\end{array}$ & $\begin{array}{c}\text { Sales } \\
\text { Difference }\end{array}$ & $\begin{array}{c}\text { Internet-based } \\
\text { in Product } \\
\text { Promotion }\end{array}$ \\
\hline 1 & Keripik Siger & 800 & Yes \\
\hline 2 & Keripik AHHAS & 300 & Yes \\
\hline 3 & $\begin{array}{c}\text { Oleh-Oleh Khas } \\
\text { Lampung "Wisa" }\end{array}$ & -300 & Yes \\
\hline 4 & Keripik Nayla & 2000 & Yes \\
\hline 5 & Saudagar & 200 & Yes \\
\hline 6 & Arabar Shop & 0 & Yes \\
\hline 7 & Keripik Wagiman & -10220 & Yes \\
\hline 8 & Askha Jaya 1 & 12000 & Yes \\
\hline 9 & Askha Jaya 2 & 12000 & Yes \\
\hline 10 & Askha Jaya 3 & 12000 & Yes \\
\hline 11 & Askha Jaya 4 & 12000 & Yes \\
\hline 12 & Sumber Rezeki & -3600 & Yes \\
\hline 13 & Keripik Yaya & 14400 & Yes \\
\hline Average Sales Difference & 3967.6923 & Yes \\
\hline & & & \\
\hline
\end{tabular}

Table 4. The Sales Difference of 2012 and 2017 With Using Internet in Product Promotion

The analysis shows disruptive technology has affected the promotion aspect while other variables have not been affected yet. The result of analysis lead to the formulation of SMEs development strategy. The strategy aims to strengthen the capacity of SMEs Banana Chips in facing the era of disruptive technology and increase the local and national competitiveness of Lampung Province. Here some strategies that can be considered in developing SMEs Banana Chips in Bandar Lampung:

1. Socialization and mentoring program on the development of marketing and sales aspects of SMEs banana chips by utilizing the online media, conducted by at least the government, private sectors and academics.

2. The cooperation between the government and bank in order to facilitates the online transaction needs of SMEs Banana Chips

3. The cooperation between the government and business sector that is professional in providing delivery service not only in the scope of local and national but also international market. 
4. City Branding enhancement of Bandar Lampung by collaboration among governments, academics, business sectors in order to promote Banana Chips as popular and authentic product of Lampung.

5. The government facilitates academics in terms of research and development of innovative banana chips products both in terms of flavor and packaging innovation.

\section{Conclusion}

The shift of people lifestyle caused by the existence of disruptive technology has been forcing all sectors to develop and upgrade their performance by improving their innovation otherwise they will be left behind. In the context of developing SMEs Banana Chips in Bandar Lampung, the most seen variable of sales that affected by disruptive technology is internet-based product promotion while the other 5 variables had not been quite affected yet by the disruptive technology. In order to sustain the SMEs Banana Chips in Bandar Lampung, there are 5 (five) strategies to win the era of disruptive technology. The strategies are emphasizing in several aspects such as using online media in promoting and marketing product, stakeholder partnership in financial support and delivery services, strengthening the city branding of Bandar Lampung, and innovation in product and packaging. The strategies are designed so that there will not be a SME Banana Chips that loses at its own home.

\section{Acknowledgement}

We would like to express my special gratitude to Allah SWT for blessing me every day. We would also like to thank my partners in this research (Fran Sinatra, Irfan, Nisfi and Laura) who help me a lot in finishing this research within the limited time frame.

\section{Reference}

Agahari, Wirawan. 2017. "Peluang dan Tantangan Ekonomi Digital di Indonesia". dalam situs www.kumparan.com yang diakses pada 3 Februari 2018.

Aruni, Yasmin. 2017. "Inovasi, Disrupsi dan Revolusi Industri 4.0". dalam Focus Group Discussion pada 19 September 2017. Bandung: ITB.

Badan Pusat Statistik Kota Bandar Lampung. 2014. Kota Bandar Lampung Dalam Angka. Bandar Lampung: BPS.

Badan Pusat Statistik Kota Bandar Lampung. 2016. Kota Bandar Lampung Dalam Angka. Bandar Lampung: BPS.

Chishakwe, Dominic B dan Wilhelmina Smith. 2012. "An Analysis of The Impact of Disruptive Technology on The Success of Small and Medim Enterprises (SMEs) in A Developing Nation. A Case of King Williams Town, South Africa". African Journal of Business Management. Vol 6 (36). pp. 10050-10060.

Hadad, Muliaman D. 2017. Financial Technology (FinTech) di Indonesia. Jakarta: IBS.

Kasali, Rhenaldi. 2017. "Meluruskan Pemahaman soal Disruption". dalam situs www.kompas.com yang diakses pada 3 Februari 2018.

Kementerian Perencanaan Pembangunan Nasional/ Badan Perencanaan Pembangunan Nasional. 2014. Rencana Pembangunan Jangka Menengah Nasional 2015-2019. Jakarta: Bappenas.

Kementerian Perindustrian. 2015. Rencana Induk Pembangunan Industri Nasional 2015-2035. Jakarta: Pusat Komunikasi Publik Kementerian Perindustrian.

Sugiyono. 2008. Metode Penelitian Kuantitatif, Kualitatif dan R\&D. Bandung: Alfabeta.

Sulaksono. 2018. "Kebijakan Industri Nasional di Era Disrupsi Teknologi". Disampaikan pada IPB Talk on Agroindustry 4.0: Tantangan dan Peluang bagi Sumberdaya Agroindustri. 15 Januari 2018.

Undang-Undang Republik Indonesia Nomor 3 Tahun 2014 tentang Perindustrian.

Winanto, Andry. 2018. "Disrupsi Jadi Peluang Inovasi dan Evolusi Industri Manufaktur". Dalam situs www.bisnis.com yang diakses pada 11 February 2018.

Zanni, Tim dkk. 2017. The Changing Landsacep of Disruptive Technologies. Swiss: KPMG. 